\title{
Labor Legislation
}

\section{As It Affects the Engineer}

According to the June 27 issue of Business Week, Rep. Kearns (R., Pa.) introduced a bill in Congress along lines suggested by the National Society of Professional Engineers, to amend the Taft-Hartley Act to permit scientific, technical, and professional groups to discuss wages, hours, and working conditions with management-with the protection and support of the federal law. The article reports that the bill is opposed by a loosely knit group of professional and technical unions, the Engineers \& Scientists of America. This group wants Taft-Hartley amended to make it an unfair labor practice for employers to discuss collective bargaining matters with professional organizations.

One interested member of AIME reported to the Institute that he felt that he had the right to discuss wages, hours, and working conditions on his own initiative with the company he worked for. He was opposed to any group, professional or union, usurping this right. He also felt that if engineers are ever to obtain professional status, it will be on the basis of their individual ability and attainment rather than on bargaining agreements that might be pressured by a group.

To clarify this matter, AIME's representative on the Engineers Joint Council Labor Panel prepared the following outline of the national Labor Act as it affects professional engineers and the part the professional societies have played in modifying it in the interest of professional employees.

As it now stands, the Taft-Hartley Act allows professional employees: 1 - To form their own collective bargaining groups; 2-to unite with some other group of their own choice; or 3-to reject collective bargaining entirely. It provides that the Labor Relations Board shall not decide that any unit is appropriate for purposes of collective bargaining if it includes both professional and nonprofessional employees unless a majority of such professional employees vote for inclusion in such a unit.

Under the original Wagner Act, no distinction was made btween professional (engineers, doctors, etc.) and other employees (carpenters, bricklayers, plumbers, etc.). A majority vote within a plant to establish a collective bargaining agency brought under the agency all employees, engineers included, whether they liked it or not, and they were governed by any instrument of bargaining executed between that agency and their employer. There was no recognized definition of a professional employee, which made it next to impossible for professional employees to form their own organization if they wanted to.

The ASCE was first to be aroused to the necessity for some action to protect the interests of a large group within their membership who came under the Act. It supported various means for maintaining the integrity of the engineer in matters of collective bargaining, and finally earned the sympathetic cooperation of other member societies of Engineers Joint Council, with the result that EJC appointed a Labor Legislation Panel in which ASEE and NSPE joined. As a result of the action of this group, following the election of a Republican Congress in 1946, a definition of a professional employee and the stipulation concerning their rights in matters of collective bargaining, as listed above, were written into the new Taft-Hartley Act.

Therefore, all engineers not bound to any organization which they have voted to recognize as their representative in matters of collective bargaining, have the right to discuss wages, hours, and working conditions on their own initiative with the company they work for.

The NSPE and EJC are concerned about an interpretation of the Taft-Hartley Act as it now stands, and as it affects technical associations. The matters in question bear on what has been termed Freedom of Association. Throughout the country there are groups of engineers banded together to discuss matters which logically come under the head of engineering and which may involve conditions of working and wages, but purely from an engineering viewpoint. The groups may be composed of representatives of management, possibly executives, as well as rank and file engineering employees. Now the present Labor Act defines a labor organization as "any organization of any kind, or any agency or employees representation committee or plan, in which employees participate and which exists for the purpose, in whole or in part, of dealing with employers concerning grievances, labor disputes, wages, rates of pay, hours of employment, or conditions of work." Under this definition the technical groups described could be called labor organizations and, as such, be subject to the regulation of the Act concerning matters of "unfair labor practices" and the like. If it be construed that any professional society exists for the purpose of dealing in part, with rates of pay, hours of employment, or conditions of work, it could be branded as a labor organization under the definition in the Labor Act.

The protection afforded such technical organizations, however, appears in the "Freedom of Speech" portion of the Act which says: "The expression of any view, argument, or opinion, or the dissemination thereof, whether in written, printed, graphic or visual form, shall not constitute or be evidence of an unfair practice under any of the provisions of this Act, if such expression contains no threat of reprisal or force or promise of benefit." Thus while under the Act the society could be branded as a labor organization by definition, it would be difficult to find it guilty of unfair labor practice under the "Freedom of Speech" provision.

The interests of the engineer cannot be taken care of by ignoring labor legislation. The AIME is not engaging in collective bargaining arrangements. Through the Labor Panel of EJC it is trying to preserve the right of the individual engineer, who has not elected to join a collective bargaining group, to discuss wages, hours, and working conditions on his own initiative with his company. Engineering groups have no desire to discuss matters of labor from the viewpoint of collective bargaining-only as a purely engineering concern.

The interest of AIME and EJC in matters of labor legislature is that which all engineers must have to preserve what independence of action the individual engineer desires. 